\title{
Teknik transplastron coeliotomy pada kura Geochelone sulcata dengan kasus bladder stone
}

\author{
Dian Ayu Kartika Sari \\ Fakultas Kedokteran Hewan, Universitas Wijaya Kusuma Surabaya, Surabaya
}

\begin{abstract}
ABSTRAK: Studi kasus ini bertujuan untuk memberikan informasi mengenai penanganan kasus bladder stone pada kura Geochelone sulcata dengan menggunakan teknik transplastron coeliotomy. African spurred tortoise atau kura sulcata jantan berusia 5 tahun dengan keluhan kehilangan nafsu makan selama 5 hari dan lendir warna putih keluar dari kloaka setiap hari. Pemeriksaan fisik menunjukkan kedua kaki belakang yang lemas dan tampak eksudat putih keluar dari kloaka. Pemeriksaan radiologi menunjukkan tampak ada peningkatan radioopasitas pada area vesica urinaria, berdasarkan hasil ini disimpulkan bahwa harus dilakukan eksplorasi transplastron coeliotomy. Anaestesi tunggal menggunakan zoletil pada tindakan operasi. Masa padat putih seberat $750 \mathrm{~g}$ dengan diameter $10 \mathrm{~cm}$ dari vesica urinaria berhasil diangkat. Pengobatan pasca operasi berlangsung hampir 2 bulan dengan perkembangan kondisi tubuh terus membaik dan nafsu makan juga terus meningkat.
\end{abstract}

Kata kunci:

bladder stone, Geochelone sulcata, transplastron, coeliotomy, tortoise

\section{- PENDAHULUAN}

Semua endapan mikroskopis atau bentukan padat polikristalin yang ditemukan pada saluran urinaria diklasifikasikan sebagai urinary calculi. Urinary calculi (urolit) ini dapat ditemukan pada kadal, chelonians, ular dan ampibi. Penyebab dari calculi ini secara pasti belum diketahui, beberapa penyebab yang muncul termasuk kekurangan nutrisi vitamin A dan D (Reavill \& Schmidt 2010). Gejala klinis yang muncul pada kasus urolit pada umumnya adalah anoreksia, konstipasi, egg binding, dysuria dan pertumbuhan yang lambat (Wright 2008). Calculi dengan permukaan yang kasar atau ukuran yang besar dapat mengiritasi dinding kantung kemih sehingga menimbulkan hematuria serta hipertropi pada dinding kantung kemih dan hyperplasia pada mukosa epitel (Reavill \& Schmidt 2010). Tulisan ini bertujuan untuk melaporkan kasus urolit pada reptil sebagai satwa eksotik yang sulit ditemukan dalam naskah ilmiah di Indonesia saat ini dan diharapkan dapat menjadi acuan dalam penanganan bladder stone pada kura-kura.

\section{- KASUS}

Anamnesis dan sinyalemen: Seekor kura darat jantan jenis sulcata bernama James, berusia kurang lebih 4 tahun, berat $11 \mathrm{~kg}$. Kura dipelihara outdoor dan pakan yang disediakan berupa sayuran hijau seperti sawi, kangkung, dan pakchoy. James dibawa ke klinik hewan DRD VETERINARY Surabaya dengan keluhan kurang lebih 5 hari nafsu makan sangat menurun, keluar lendir berwarna putih dari kloaka setiap hari, mata berair, sering merejan. Penanganan dan diagnosa penunjang: Hari pertama diberikan infus intracoelomic sebanyak $3 \mathrm{ml}$ dan dilakukan x-ray. Radiografi diambil dengan posisi dorso ventral, terdapat peningkatan opasitas di pusat rongga coelomic, batu kalkuli dengan diameter sekitar $10 \mathrm{~cm}$ dan distensi gas pada saluran pencernaan (Gambar 1A). Diagnosa: Urinary calculi.

Terapi: Operasi dilakukan pada hari kedua dengan teknik transplastron coeliotomy. Vesica urinaria mengalami hypertropi, ginjal, hepar dan organ lain tampak normal. Kondisi post operasi, selama 20 hari tidak mau makan tetapi infus terus diberikan. Hari berikutnya mulai makan sedikit, dengan makanan awal berupa sayuran hijau dan bunga sepatu. James dinyatakan sehat setelah 13 hari kemudian dan dapat dibawa pulang.

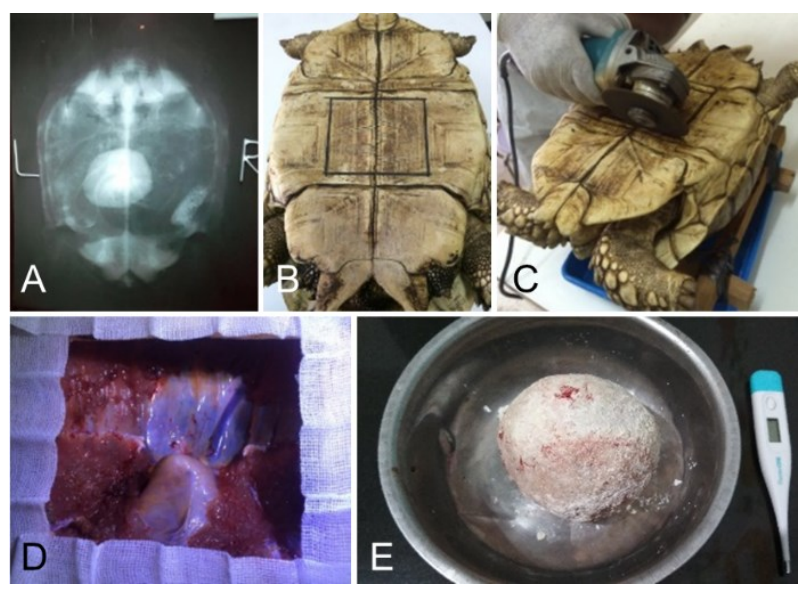

Gambar 1. Kura James dengan urinary calculi. (A) Citra radiografi, (B) tanda daerah potongan, (C) coeliotomy, (D) coelomic, dan (E) bladder stone.

Diterima: 28-02-2020 | Direvisi: 30-03-2020 | Disetujui: 01-04-2020

(C) 2020 CC-BY-SA. Ini adalah artikel Open Access yang didistribusikan berdasarkan ketentuan dari Creative Commons Attribution ShareAlike 4.0 International License (https://creativecommons.org/licenses/by-sa/4.0/). 


\section{Operasi transplastron coeliotomy}

Penanganan dan pengekangan: Anestesi yang digunakan adalah zoletil, perpaduan zolazepam dan tiletamin, dosis 10 $\mathrm{mg} / \mathrm{kg}$ diberikan secara intramuskuler. Kura diposisikan ventro-dorsal, area yang akan dipotong ditandai sesuai dengan posisi batu pada citra X-ray (Gambar 1B).

Transplastron Coeliotomy: Plastron dipotong dengan gerinda tangan dan cairan infus terus membasahi selama prosesnya (Gambar 1C). Potongan plastron yang sudah diambil direndam dalam cairan infus hingga terendam sempurna. Membran coelomic tampak setelah plastron terbuka. Garis tengah membran coelomic diinsisi menggunakan scalpel dengan blade nomor 10 dan isi dari rongga coelomic terlihat (Gambar 1D). Vena abdominalis di bagian ventral terlihat, terdapat 2 vena di tengah dengan arah cranio-caudal.

Vesica urinaria langsung terlihat dan tampak berisi masa padat berwarna putih dan tidak dapat ditarik keluar dari rongga coelomic, sehingga cystotomy dilakukan di dalam rongga coelomic. Insisi vesica urinaria dilakukan dan bladder stone dengan diameter $10 \mathrm{~cm}$ dan berat $750 \mathrm{~g}$ dikeluarkan dari tubuh kura (Gambar 1E).

Cairan salin hangat digunakan untuk membersihkan vesica urinaria dari sisa dan serpihan bladder stone, dan untuk mengembalikan kelembaban mukosa. Vesica urinaria ditutup dengan jahitan simple continuous menggunakan benang safil 3/0 dan dimasukkan dalam rongga coelomic. Membran coelomic dijahit simple continuous menggunakan benang safil 3/0. Plastron dipasang kembali dan sisi-sisi potongan diberikan antibiotik serbuk, diberikan kawat kasa dan lem untuk menutup dan memperkuat plastron.

Post-operatif: Post operasi diberikan Enrofloxacin dosis 10 $\mathrm{mg} / \mathrm{kg}$, Analgesik $10 \mathrm{mg} / \mathrm{kg}$, multivitamin injeksi $0,15 \mathrm{mg} / \mathrm{kg}$ secara intramuskular (Carpenter et al. 2001). Kura James selama hampir 1 bulan tidak mau makan sehingga infus via intracoelomic terus diberikan. Pakan campuran berbagai macam sayur dan pelet untuk merangsang nafsu makan kemudian mulai diberikan. Pengobatan di klinik berlangsung hampir 2 bulan, perkembangan kondisi tubuh terus membaik, dan nafsu makan juga terus meningkat.

\section{- HASIL DAN PEMBAHASAN}

Operasi pengangkatan cystic calculi pada umumnya disebut cystotomi. Cystotomi pada kura berbeda dengan hewan lain karena kura memiliki plastron dan karapas yang cukup keras sebagai bagian terluar dari tubuh (Taylor \& O'Shea 2014). Salah satu teknik operasi pada kura-kura untuk kasus bladder stone adalah dengan membuka plastronnya (Che'Amat et al. 2012). Plastrotomy umum dilakukan karena dapat langsung mengakses vesica urinaria, namun masa pemulihan pascaoperasi yang lama (Divers \& Mader 2005). Terdapat beberapa kondisi yang dapat terjadi dengan teknik ini, yaitu plastron yang tidak dapat menutup, terjadi perdarahan karena terpotongnya vena, kontaminasi bakteri yang menyebabkan coelomitis, serta trauma pericardium (McArthur et al. 2008).
Bladder stone pada kura darat tersusun dari asam urat dan min-eral seperti sodium, potassium dan kalsium (Wright 2008). Urea merupakan bentuk buangan utama nitrogen pada kondisi kura yang terhidrasi dengan baik dan mendapatkan minum cukup. Pembentukan urea membutuhkan sedikit energi dibandingkan dengan pembentukan asam urat, tetapi lebih toxic sehingga membutuhkan lebih banyak air sebagai pelarut untuk mencegah terjadinya kerusakan jaringan (Gibbons \& Avian 2007). Sebaliknya, pembentukan asam urat membutuhkan energi yang lebih tinggi tetapi tidak mudah terlarut dalam air dan tidak toxic dibandingkan dengan urea (Reavill \& Schmidt 2010).

Patofisiologi bladder stone pada kura darat hingga saat ini masih belum diketahui secara pasti (Wright 2008). Vesica urinaria pada reptil merupakan tempat penampungan atau penyimpanan air selama masa kering dan jika tubuh membutuhkan air dapat ditarik dari urin (Reavill \& Schmidt 2010). Dinding vesica urinaria tortois memiliki silia yang mengikat materi padat sehingga tetap di dalamnya, contohnya adalah mikrokristal urat. Walaupun konsentrasi urat sangat tinggi, suspensi tetap berbentuk cairan dan mampu melewati uretra (Gibbons \& Avian 2007).

\section{- SIMPULAN}

Teknik transplastron coeliotomy merupakan salah satu teknik pengangkatan massa bladder stone pada kura-kura yang cukup baik dan mudah dilakukan. Teknik ini dapat dilakukan jika kondisi massa bladder stone cukup besar dan tidak dapat dikeluarkan tanpa operasi. Pasca operasi membutuhkan perawatan intensif untuk peningkatan kondisi kura dan persembuhan area plastron.

\section{- INFORMASI PENULIS}

Penulis untuk Korespondensi

DAKS: deeanvet@gmail.com

Fakultas Kedokteran Hewan, Universitas Wijaya Kusuma

Surabaya. Jl. Dukuh Kupang XXV/ 54 Surabaya, Jawa Timur.

\section{- PUSTAKA ACUAN}

Carpenter JW, Ted YM, David JR. 2001. Exotic Animal Formulary. Second Edition. WB Saunders Company.

Che'Amat A, Gabriel B, Chee NW. 2012. Cystic calculi removal in African spurred Tortoise (Geochelone sulcata) using transplastron coeliotomy. Veterinary World. 5(8):489-492.

Divers SJ, Mader DR, editors. 2005. Reptile Medicine and Surgery-EBook. Elsevier Health Sciences. Dec 13.

Gibbons PM, Avian P. 2007. Reptile and amphibian urinary tract medicine: diagnosis and therapy. Proceedings Association of Reptilian and Amphibian Veterinarians. New Orleans, Louisiana. Apr 15:69-86.

McArthur S, Wilkinson R, Meyer J, editors. 2008. Medicine and surgery of tortoises and turtles. John Wiley \& Sons. Apr 30.

Reavill DR, Schmidt RE. 2010 Urinary tract diseases of reptiles. Journal of Exotic Pet Medicine. 19(4):280-289.

Taylor B, O'Shea M. 2014. The Great Big Book of Snakes and Reptiles. Hermes House. London.

Wright K. 2008. Clinical Management of Bladder Stones in Tortoises. NAV Conference. Arizona Exotic Animal Hospital, LLC Meza, AZ. 
